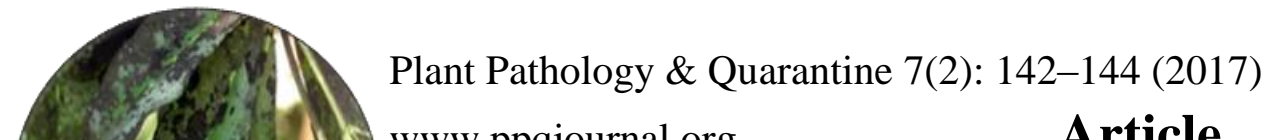

ISSN 2229-2217 www.ppqjournal.org

Article

\author{
Doi 10.5943/ppq/7/2/6 \\ Copyright $\odot$ Mushroom Research Foundation
}

\title{
Euoidium vernoniicola, a new report for Pakistan
}

\author{
Afshan $\mathrm{NS}^{1 *}$, Khanum $\mathrm{S}^{2}$, Fiaz $\mathrm{M}^{2}$, Khalid $\mathrm{AN}^{3}$ and Niazi $\mathrm{AR}^{3}$ \\ ${ }^{1}$ Centre for Undergraduate Studies, University of the Punjab, Quaid-e-Azam Campus, Lahore, Pakistan. \\ ${ }^{2}$ Department of Botany, Hazara University, Mansehra, Pakistan \\ ${ }^{3}$ Department of Botany, University of the Punjab, Quaid-e-Azam Campus, Lahore, 54590, Pakistan
}

Afshan NS, Khanum S, Fiaz M, Khalid AN, Niazi AR 2017 - Euoidium vernoniicola, a new report for Pakistan. Plant Pathology \& Quarantine 7(2), 142-144, Doi 10.5943/ppq/7/2/6

\begin{abstract}
Euoidium vernoniicola is recorded for the first time from Pakistan. It is also the first time that the genus Euoidium has been reported from Pakistan. Nine genera of powdery mildews are now known for Pakistan.
\end{abstract}

Key words - Erysiphales - pathogenic fungi - Vernonia elaeagnifolia

\section{Introduction}

Vernonia Schreb. is a genus of about 1000 species of forbs and shrubs in the family Asteraceae. Some species are known as ironweed, and some are edible and of economic value. They are known for having intense purple flowers. The genus is named for the English botanist William Vernon. There are numerous distinct subgenera and subsections in this genus. This has led some botanists to divide this large genus into several distinct genera. During a survey of plants infected with powdery mildews, a plant of Vernonia elaeagnifolia was found infected with this fungal pathogen. V. elaeagnifolia is native to India, Myanmar and Thailand. Common names include curtain creeper, Vernonia creeper and parda bel and in Pakistan, it is also known as sehra bel. It is a creeper which finds it difficult to climb without support. So, the slender stems climb up and then fall down beautifully over a wall or railing. The tender stems, all hanging down form a curtain, hence the name curtain creeper. Primarily it is a foliage plant, grown for its habit of forming a green curtain (Robinson et al. 2008, Ghafoor 2015). Recently, after careful examination, a powdery mildew was found on $V$. elaeagnifolia in Pakistan and it was identified as Euoidium vernoniicola, which is a new record for Pakistan. Previously about 4500 species of fungi are known from Pakistan (Anwar \& Shank 2002) with about 8 genera and 23 species of powdery mildews (Erysiphales) (Ahmad et al. 1997). This work has raised the number of known powdery mildew fungi from Pakistan.

\section{Materials \& Methods}

Specimens were collected from Lahore, Punjab \& Mansehra, KPK, Pakistan in winter seasons 2015, 2016 and transferred to the laboratory of fungal biotechnology, University of Punjab, Lahore. The host plant was identified by a taxonomist and by comparison with previously identified specimens. For microscopic observation, different parts of the fungus were mounted in lactic acid on glass slides and examined using a light microscope with phase contrast $20 \times$ and $40 \times$ 
objectives. Size dimensions were determined for 15 conidia and conidiophores from each infected plant. Morphological characteristics of asexual stages, kind of host and other information related to each species were examined. In addition to comparison using light microscopy, images of the infected portion, conidia and conidiophores were obtained and drawn using a Camera Lucida. Exact identification and confirmation of taxa were done using manuals of Braun (1987), Ahmad et al. (1997) and Braun \& Cook (2012). Specimens were deposited in the herbarium of Botany Department, University of the Punjab, Lahore, Pakistan.

\section{Results \& Discussion}
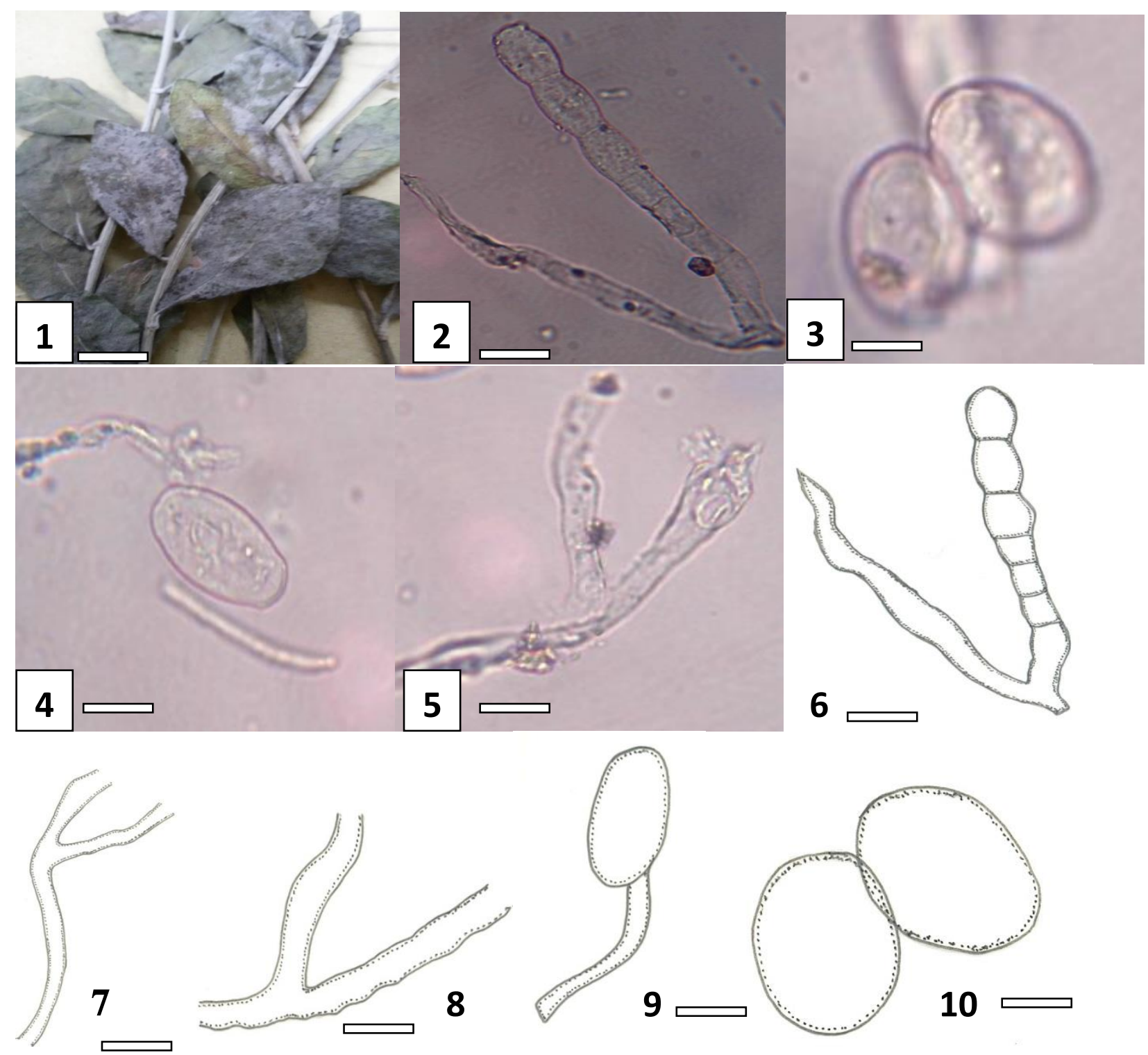

Figs 1-10 - 1, Infected leaves of Vernonia elaeagnifolia. 2, Conidiophore. 3, Conidia. 4, Germinating conidium. 5, Hyphae. 6, Drawing of conidiophore. 7, Hyphae. 8, Foot cell. 9, Germinating conidium. 10, Conidia. - Bars $=10 \mu \mathrm{m}$

Euoidium vernoniicola (Bappamm., Hosag. \& Udaiyan) U. Braun \& R.T.A. Cook. Taxonomic Manual of the Erysiphales (Powdery Mildews): 338 (2012)

Figs $1-10$

Mycelium amphigenous, in the form of white irregular patches, persistent, mostly on leaves, dense; hyphae branched, septate, hyaline, thin-walled, 5-7 $\mu \mathrm{m}$ thick. Conidiophores hyaline with a yellowish tinge, erect, straight, up to $140 \mu \mathrm{m}$ long; foot cells straight, hyaline, cylindrical, 25-60(- 
70) $\mu \mathrm{m}$ long and 9-11 $\mu \mathrm{m}$ wide, followed by 1-2 shorter cells, forming catenate conidia. Conidia cylindrical to ovoid or doliiform, hyaline, 15-20 × 31-40 $\mu \mathrm{m}$.

Known distribution - Asia (India, Tamil Nadu).

Material examined - On leaves of Vernonia elaeagnifolia DC., Pakistan, Khyber Pakhtunkhwa, Mansehra district, Phulra, $1088 \mathrm{~m}$ a. s. 1., December 2015, M. Faiz, K. Habib, S. Khanam No. S. K 9; on Vernonia elaeagnifolia, Pakistan, Punjab, Lahore district, November 2016, A.N. Khalid \& A.R. Niazi, No. AN20.

Euoidium vernoniicola is a new record for Pakistan. Euoidium vernoniicola contains Euoidium type conidiophores with conidia maturing in chains but the conidiogenous cell remains unswollen. This type is the asexual state of section Erysiphe Blumer of the genus Erysiphe R. Hedw. ex DC. and of the genera Sphaerotheca Lév. and Podosphaera Kunze. Previously the genus Euoidium was not reported from Pakistan. In Asia, it is found only in India, Tamil Nadu (Braun \& Cook 2012). This is also the second report of this species from any Asian country.

\section{Acknowledgements}

We are highly grateful to the University of the Punjab, Lahore, for providing funds to carry out this research work.

\section{References}

Ahmad S, Iqbal SH, Khalid AN. 1997 - Fungi of Pakistan. Sultan Ahmad Mycological Society Pakistan, Department of Botany, University of Punjab, Lahore, Pakistan. pp. 32-236.

Anwar M, Shank CC. 2002 - Biodiversity planning in Asia. IUCN, Gland, Switzerland and Cambridge, UK. pp. 430-447.

Braun U. 1987 - A monograph of the Erysiphales (powdery mildews). Beihefte zur Nova Hedwigia 89, 1-700.

Braun U, Cook RTA. 2012 - Taxonomic manual of the Erysiphales (powdery mildews).

Ghafoor A. 2015 - Asteraceae Subfam. Cichorioideae Trib. 3. Vernonieae. Flora of Australia. In: Wilson AJG (ed.), 37, 188.

Robinson HSC, Keeley JJ, Skvarla, Chan R. 2008 - Studies on the Gymnantheminae (Vernonieae: Asteraceae) III: restoration of the genus Stroboealyx and the new genus Tarlmounia. Proceedings of the Biological Society of Washington 121, 19-33. 